\title{
Correction to: Tapentadol Prolonged Release: A Review in Pain Management
}

\author{
Emma D. Deeks ${ }^{1}$
}

Published online: 21 March 2019

(c) Springer Nature 2019

\section{Correction to: Drugs (2018) 78:1805-1816 https://doi.org/10.1007/s40265-018-1007-2}

The article Tapentadol Prolonged Release: A Review in Pain Management, written by Emma D. Deeks, was originally published Online First without open access. After publication in volume 78 , issue 17 , pages $1805-1816$ Grünenthal $\mathrm{GmbH}$, Germany requested that the article be Open Choice to make the article an open access publication. Post-publication open access was funded by Grünenthal $\mathrm{GmbH}$, Germany. The article is forthwith distributed under the terms of the Creative Commons Attribution-NonCommercial 4.0 International License (http://creativecommons.org/licen ses/by-nc/4.0/), which permits any noncommercial use, duplication, adaptation, distribution and reproduction in any medium or format, as long as you give appropriate credit to the original author(s) and the source, provide a link to the Creative Commons license and indicate if changes were made.

The original article has been corrected.

Open Access This article is distributed under the terms of the Creative Commons Attribution-NonCommercial 4.0 International License (http://creativecommons.org/licenses/by-nc/4.0/), which permits any noncommercial use, distribution, and reproduction in any medium, provided you give appropriate credit to the original author(s) and the source, provide a link to the Creative Commons license, and indicate if changes were made.
The original article can be found online at https://doi.org/10.1007/ s40265-018-1007-2.

Emma D. Deeks

demail@springer.com

1 Springer, Private Bag 65901, Mairangi Bay, Auckland 0754, New Zealand 